\title{
PENERAPAN METODE TOTAL QUALITY MANAJEMEN DALAM PENDIDIKAN
}

\section{Nur Diana Kholidah}

\section{Email: dianarun46@gmail.com}

\begin{abstract}
Abstrak: Prestasi belajar di nyatakan meningkat apabila indikator prestasi belajar meningkat yang meliputi aspek kognitif, dan psikomotorik. Metode Total Quality Manajemen atau yang di kenal metode peningkatan mutu terpadu adalah konsep manajemen sekolah sebagai sebuah inovasi dalam menyelenggarakan pendidikan di sekolah yang diharapakan dapat memberikan perubahan yang lebih baik sesuai dengan perkembangan tuntutan dan dinamika masyarakat dalam menjawab permasalahan-permasalahan pengelolaan pendidikan pada tingkat sekolah. Justru setiap sekolah ingin mengeluarkan lulusan yang baik dan bisa mengimplementasikan dengan baik kelak di masyarakat. Sebuah institusi dapat memutuskan untuk mengawali inisiatif TQM dengan BS5750 atau ISO9000, namun ini bukan cara baku yang harus di ikuti. Institusi dapat menentukan sistem mutunya sendiri. Yakni dengan cara melakukan metodemetode total quality yang ada, sebagai cara untuk menunjukkan bahwa kepuasan pelanggan itu menjadi acuan utamanya. Plan-Do-chek-act ini menjadi tujuan utama dalam penerapan metode total quality.
\end{abstract}

\section{A. Pendahuluan}


Penerapan yang berasal dari kata terap yakni adalah terukir dengan imbuhan pe dan an yang berarti proses suatu cara untuk menerapkannya.

Penerapan adalah suatu perbuatan memperaktikan suatu teori, metode dan dan lain-lain untuk mencapai tujuan tertentu dan untuk suatu kepentingan yang di inginkan oleh suatu kelompok atau suatu golongan yang telah terencana dan tersusun sebelumnya.

Sedangkan metode ialah prosedur atau cara yang ditempuh untuk mencapai tujuan tertentu. Kemudian ada salah satu istilah lain yang erat kaitannya dengan dua istilah ini tekni atau cara yang spesifik dalam memecahkan masalah tertentu yang ditemukan dalam melaksanakan prosedur.

Dalam hal ini penulis akan membaha tentang Penerapan Metode Total Qulity Manajemen dalam Pendidikan.

Pembangunan bidang pendidikan yang dilaksanakan oleh pemerintah bersasama dengan masyarakat dalam rangka upaya mewujudkan salah satu cita-cita yang sangat mulia dan luhur, yaitu mencerdaskan kehidupan bangsa sebagaimana termaktup dalam UUD'45 dalam upaya tersebut, masyarakat juga pemerintah bergotong royong untuk mencerdaskan seluruh bangsa dengan demikian, lembaga pendidikan harus di usahakan berupa langkah-langkah adanya inovasi pendidikan secara profesional dengan manajemen yang sangat handal, sehingga lembaga pendidikan tersebut bisa mencetak out put yang ready di tengah-tengah masyarakat baik siap dalam iktelektualnya maupun spiritualnya. Sebuah institusi dapat memutuskan untuk mengawali inisiatif TQM dengan BS5750 atau ISO9000, namun ini bukan cara baku yang harus di ikuti. Institusi dapat menentukan sistem mutunya sendiri. Dengan demikian, ia dapat mengawasi sistem dan prosedur melalui ukuran standar yang mereka tentukan sendiri. Institusi yang efektif membutuhkan strategistrategi yang bertujuan dan kuat agar mampu meraih hasil yang kompetitif. Untuk mengembangkan strategi mutu, institusi memerlukan:

- Misi yang jelas dan disnigtif.

- Fokus pelanggan yang jelas.

- Keterlibatan seluruh pelanggan dalam mengambangkan strategi.

- Pemberdayaan staf dengan cara menghilangkan kendala dan membantu mereka dalam memberi konstribusi maksimum pada institusi melalui pengembangan kelompok kerja efektif. 
- Penilaian dan evaluasi efektifitas institusi dalam mencapai tujuan yang berhubungan dengan pelanggan. ${ }^{1}$

Institusi yang melaksanakan cara ini bisa jadi akan kewalahan dalam menghadapi tugas yang sangat besar dan beraneka peringatan akan bahaya kelumpuham mutu terpadu.

\section{B. Penerapan Metode Total Qulity Manajemen Dalam Pendidikan}

Mutu muncul dari sebuah proses. Mutu juga merupakan sistem manajemen yang dapat di gunakan untuk mengimplementasikan model perbaikan lembaga pendidikan dan segala hal yang berkaitan dengan pendidikan. ${ }^{2}$

Pengertian manajemen ialah sebuah proses dalam rangka untuk mencapai suatu tujuan organisasi dengan cara bekerja sama dengan orang-orang dan sumber daya yang dimiliki oragnisasi. ${ }^{3}$ Sedangkan yang telah di kemukakan oleh Mary Parker Follet adalah seni dalam menyelesaikan sesuatu melalui orang lain. ${ }^{4}$

Pendidikan ialah pembelajaran dan pembiasaan sekelompok orang yang diturunkan dari satu generasi ke generasi berikutnya melalui pengajaran, pelatihan atau penelitian. Pendidikan sering terjadi di bawah bimbingan orang lain, tetpi juga memungkinkan secara otodidak. ${ }^{5}$

Yang menjadi masalah dalam dunia pendidikan ialah masih rendahnya mutu keluarannya. Sesuatu yang menjadi acuan untuk menguatkan pernyataan tersebut adalah Nilai ujian nasional yang murni yang secara umum tidak lebih kurang menggembirakan. Peningkatan mutu ini telah lama di bicarakan oleh pemerintah untuk mengembangkan kebijakan pembangunan pendidikan, dengan membuat empat kebijakan startegis yang terdiri atas keluasan pembelajaran, meningkatkan mutu pendidikan, meningkatkan relevansi, serta efesien dan efektivitas penyelenggara pendidikan. Selain itu juga harus mengadakan serangkaian kegiatan pelatihan guru, pembentukan musyawarah guru mata pelajaran dan lain sebagainya. Salah satu kunci untuk meningkatkan mutu pendidikan ialah kita harus memberikan rasa puas kepada siswa, orang tua dan masyarakat. Mutu pendidikan berkembang seirama dengan tuntutan kebutuhan hasil pendidikan yang berkaitan dengan kemajuan ilmu teknologi

\footnotetext{
${ }^{1}$ Edward Sallis, Manajemen Mutu Terpadu Pendidkan, ( Jogjakarta; IRCSoD, 2010) Hal. 244

${ }^{2}$ Moh. Rifa'i, Commoni Emprowermen in Islamic boarding school.( Kraksaan, CV. Mandiri. 2017) Hal: 68

${ }^{3}$ http://nichonotes.blogspot.nl/2015/02/pengertian-manajemen.html

${ }^{4}$ Ernie Tisnawati Sule \& Kurniawan Saefullah, Pengantar Manajemen, (Jakarta; Kencana Prenada Media Grup, 2005) Hal.5

${ }^{5}$ Dewey John,(1916-1944) Democracy dan education, The Free Press: Hal 1-4 ISBN0-684-83631--9
} 
yang melekat pada wujud pengembangan kualitas sumber daya manusia. Supaya manajemen pendidikan ini efektif dan efesien, diperlukan komitmen yang sungguhsungguh dalam meningkatkan mutu. Dalam total quality manajamen menekankan dua konsep utama yakni sebagai filosofi perbaikan terus menerus (continous impeovement) dan yang kedua berhubungan dengan alat-alat teknik seperti analisi kekuatan lapangan, yang di gunakan untuk perbaikan kuliatas dalam tindakan dalam manajemen untuk mencapai kebutuhan dan harapan pelanggan. Untuk bisa menyenangkan konsumen dalam pendidikan maka perlu perbaiakn program sekolah yang mungkin atau lebih layak di lakukan secara kreatif dan konstruktif, dan yang paling penting adalah bagaimana mutu kuliatas dalam program dapat mengubah kultur sekolah yang mana siswa dan orang tua menjadi tertarik dengan adanya pemasukan yang di timbulkan.

Dalam rangka melaksanakan peningkatan qulitas pendidikan perlu melaksanakan metode yang dikenal dengan PDCA (Plan-Do-Chek-act). Metode ini pertama kali di kembangkan oleh Sheward dan divisualisasikan oleh Deming, berupa siklus PDCA tersebut ialah sebagai berikut:

\section{a. Metode W. Edwards Deming}

1. Mengembangkan rencana perbaikan (Plan). Ini merupakan langkah setelah di lakukan pengujian ide perbaikan masalah. Rencana perbaiakn di susun berdasarkan prinsip 5W (what, why, who, when, dan where)dan $1 \mathrm{~h}$ (how), yang di buat secara jelas dan terinci serta menetapkan sasaran dan target yang harus di capai. Dalam menetapkan sasaran dan target herus memperhatikan prinsip SMART (specific, measurable, attainable, reasonable, dan time).

2. Melaksanakan recana (do). Rencana yang telah di susun di implementasikan secara bertahap, mulai dari skala kecil yang pembagian tugas secara merata sesuai dengan kapasitas dan kemampuan setiap personil. Selama dalam melaksanakan rencana harus dilakukan pengendalian yaitu mengupayakan agar seluruh rencana di laksanakan dengan baik sebaik mungkin sasaran dapat di capai.

3. Memeriksa atau meneliti hasil yang di capai (check). Memrriksa atau meneliti hasil merujuk pada penetapan apakah pelaksanaannya berada dalam jalur, sesuai dengan rencana dan memantau kemajuan perbaikan 
yang di rencanakan. Alat atau piranti yang dapat di gunakan dalam memeriksa adalah pareto diagram, histogram, dan diagram kontrol.

\section{Melakukan tindakan penyesuaian bila di perlukan (action).}

Penyesuaian di lakukan bila di anggap perlu, yang didasarkan hasil analisis di atas. Penyesuaian berkaitan dengan standarisasi prosedur baru guna menghindari timbulnya kembali masalah yang sama atau menetapkan sasaran baru bagi perbaikan berikutnya.

Untuk memproleh mutu yang sangat baikpastinya kita butuh perencaan yang sangat matang. Krean total quality manajemen adalah sesutu yang bisa di raih dengan berkelanjutan, untuk bisa meraih semua itu, maka kesalahan harus dieleminasi untuk mencapi keunggulan alumninya. Menurut Joseh C. Field ada sepuluh langkah untuk menerapkan metode total quality dalam pendidikan yaitu:

1. Mempelajari dan memahami total quality manajemen secara menyeluruh.

2. Memahami dan mengambil jiwa dan filosofi untuk perbaikan terusmenerus.

3. Menilai jaminan kualitas saat ini dan program pengendalian mutu.

4. Membangun kebijakan kualitas, rencana strategi mutu, implementasi rencana, rencana pelatihan, organisasi dan struktur, prosedur bagi tindakan perbaikan, pendifinisian terhadap nilai tambahan tindakan.

5. Mempersiapkan orang-orang untuk berubah, melatih orang-orang untuk bekerja pada suatu kelompok.

6. Mempelajari teknik untuk menyerang akar persoalan dan mengaplikasikan tindakan koreksi dengan menggunakan teknik dan alat total quality manajemen.

7. Memilih dan menetapkan pilot dan project untuk di aplikasikan.

8. Menetapkan prosedur tindakan pebaiakn dan sadari akan keberhasilannya.

9. Menciptakan perjanjian dan strategi yang benat mutu terpadu oleh pemimpin yang akan menggunakannya.

10. Memelihara jiwa mutu terpadu dalam penyelidikan dan aplikasi pengetahuan yang amat luas. 


\section{b. Metode Joseph M. Juran}

Joseph M. Juran mendinisikan kualitas sebagai cocok atau sesuai untuk di gunakan (fitness for use), yang mengandung pengertian bahwa suatu barang atau jasa harus dapat memenuhi apa yang di harapkan oleh para pemakainya. Konstribusi Joseph M. Juran yang paling terkenal adalah jurans basic steps to progres, tiga langkah dasar ini merupakan langkah yang harus di lakukan perusahaan bula mereka ingin mencapai kualitas tingkat dunia. Joseph M. Juran juga yakin bahwa ada titik diminishing return dalam hubungan atara kualitas dan daya saing. Diantaranya adalah

1. Mencapai perbaikan struktur atas dasar kesinambungan yang dikombinasikan dengan dideksi dan keadaan yang mendesak.

2. Mengadakan program pelatihan secara luas.

3. Memebantu komitmen dan kepemimpinan pada tingkat manajemen yang lebih tinggi.

Sebagaimana yang sudah di bahas di atas, pendidikan yang bermutu berlandaskan kepada pelanggan yang sesuai sasaran utama baik pelanggan dalam maupun pelanggan luar yang di maksud dengan pelangan luar dalam pendidikan ialah pengelolah institusi pendidikan, yakni guru staff, dan penyelenggara institusi. Sedangkan pelanggan luar meneurut pendidikan ialah masyarakat, pemerintah, dan dunia industri. Tentang peningkatan kualitas sistem layanan jasa pendidikan secara berkelanjutan, terus-menerus dan terpadu. Pencapaian tujuan tersebut dapat di wujudkan dengan menggunakan prinsip-prinsip berupa: pemfokusan pada pelanngan sekolah, peningkatan kualitas proses, dan melibatkan semua komponen lembaga.

1. Perbaikan Secara Terus Menerus, agar output yang sudah kita keluarkan menjamin semua pihak baik pelangan luar maupun dalam.

2. Menentukan Standar Mutu, untuk menetapkan standar-standar mutu dari semua komponen yang bekerja dalam proses prduksi atau transformasi lulusan istitusi pendidikan.

3. Perubahan kultur, bertujuan untuk membudayakan organisasi yang dapat menghargai mutu dan bisa menjadikan mutu sebagai orientasi semua komponen organisasional.

4. Perubahan organisasi, ini bukan berarti perubahan wadah organisasi, melainkan sistem atau strukturorganisasi yang melambangkan hubungan- 
hubungan kerja dan kepegawaian dalam organisasi yang menyangkut perubaham kewenangan, tugas-tugas dan tanggung jawab.

5. Mempertahankan Hubungan Dengan Pelanggan, ini sangat penting karena apa yang kita buat harus bisa membuat pelannggan itu puas, dan ini yang harus di pertahankan dalam penerapan metode. ${ }^{6}$ 


\section{Kesimpulan}

metode ialah prosedur atau cara yang ditempuh untuk mencapai tujuan tertentu. Kemudian ada salah satu istilah lain yang erat kaitannya dengan dua istilah ini tekni atau cara yang spesifik dalam memecahkan masalah tertentu yang ditemukan dalam melaksanakan prosedur. Dalam rangka melaksanakan peningkatan qulitas pendidikan perlu melaksanakan metode yang dikenal dengan PDCA (Plan-Do-Chekact) yaitu: Mengembangkan rencana perbaikan (Plan), melaksanakan recana (do), memeriksa atau meneliti hasil yang di capai (check), melakukan tindakan penyesuaian bila di perlukan (action), menurut metode W. Edwards Deming. Ada juga metode menurut Joseph M. Juran yakni perbaikan secara terus menerus, menentukan standar mutu, perubahan kultur, perubahan organisasi, dan mempertahankan hubungan dengan pelanggan. 


\section{DAFTAR RUJUKAN}

Sallis Edrward, Manajemen Mutu Terpadu Pendidkan, (Jogjakarta: IRCSoD, 2010).

Rifa'i Moh, Emprowermen in Islamic boarding school, .( Kraksaan, CV. Mandiri. 2017).

http://nichonotes.blogspot.nl/2015/02/pengertian-manajemen.html.

Tisnawati Sule, Ernie \& Kurniawan Saefullah, Pengantar Manajemen, (Jakarta; Kencana Prenada Media Grup, 2005).

John Dewey, Democracy dan education, The Free Press (1916-1944).

Mundiri, A. (2016). THE LEADERSHIP OF HEADMASTER IN BUILDING A WORK CULTURE BASED ON PESANTREN. In International Conference on Education and Training (pp. 1-7). Malang: Faculty of Education State University of Malang.

Mundiri, A. (2017). Organizational Culture Base On Total Quality Management In Islamic Educational Institution. ADRI International Journal Of Islamic Studies and Social Sciences, 1(1), 1-11.

Mundiri, A., \& Zahra, I. (2017). Corak Representasi Identitas Ustadz dalam Proses Transmisi Pendidikan Karakter di Pesantren. Jurnal Pendidikan Islam, Vol. 2, No, 21-35.

http://aa-den.blogspot.nl/2010/07/total-quality-management-tqm-dan.html Diakses pada 21 Maret 2018 